Article

\title{
Synthesis, Anti-HCV, Antioxidant and Reduction of Intracellular Reactive Oxygen Species Generation of a Chlorogenic Acid Analogue with an Amide Bond Replacing the Ester Bond ${ }^{\dagger}$
}

\author{
Ling-Na Wang ${ }^{1,2}$, Wei Wang ${ }^{3}$, Masao Hattori ${ }^{4}$, Mohsen Daneshtalab ${ }^{5}$ and Chao-Mei Ma ${ }^{1, *}$ \\ 1 College of Life Sciences, Inner Mongolia University, Huhhot 010021, China; shxywln@163.com \\ 2 College of Biochemical Engineering, Huhhot Vocational College, Huhhot 010058, China \\ 3 Department of Chemistry, School of Pharmaceutical Sciences, Kunming Medical University, \\ Kunming 650500, China; wangwei.kmu@hotmail.com \\ 4 Institute of Natural Medicine, University of Toyama, 2630 Sugitani, Toyama 930-0194, Japan; \\ mhattori@po4.canet.ne.jp \\ 5 School of Pharmacy, Memorial University of Newfoundland, St. John's, NL A1B 3V6, Canada \\ * Correspondence: cmma@imu.edu.cn; Tel./Fax: +86-716-499-2435 \\ + This paper is dedicated to our respected late Professor, Dr. Mohsen Daneshtalab.
}

Academic Editor: Jean Jacques Vanden Eynde

Received: 16 May 2016; Accepted: 31 May 2016; Published: 8 June 2016

\begin{abstract}
Chlorogenic acid is a well known natural product with important bioactivities. It contains an ester bond formed between the $\mathrm{COOH}$ of caffeic acid and the 3-OH of quinic acid. We synthesized a chlorogenic acid analogue, $3 \alpha$-caffeoylquinic acid amide, using caffeic and quinic acids as starting materials. The caffeoylquinc acid amide was found to be much more stable than chlorogenic acid and showed anti-Hepatitis $\mathrm{C}$ virus (anti-HCV) activity with a potency similar to chlorogenic acid. The caffeoylquinc acid amide potently protected HepG2 cells against oxidative stress induced by tert-butyl hydroperoxide.
\end{abstract}

Keywords: 3-caffeoylquinic acid amide; synthesis; anti-HCV; anti-oxidant; cellular oxidative stress

\section{Introduction}

Chlorogenic acid is a natural product containing an ester bond formed between the $\mathrm{COOH}$ of caffeic acid and the 3-OH of quinic acid. Chlorogenic acid has been well known to have antioxidant and anti-viral activities, and the potential to be effective against type II diabetes, cardiovascular disease and some aging-related diseases [1-4]. Recent studies demonstrated that chlorogenic acid could attenuate $\mathrm{d}$-galactolse-induced chronic liver and kidney injury, and the protection may be due to its antioxidative and anti-inflammatory effects [5]. Chlorogenic acid also showed therapeutic potential for inhibiting inflammatory hyperplasia of the synovium in patients with rheumatoid arthritis [6]. Using PC12 cells which are similar to neurons, researchers demonstrated that chlorogenic acid could increase the cell's viability and differentiation by preventing the cells from alcohol-induced apoptosis [7]. Chlorogenic acid is used as a bioactive marker constituent for the quality control of some important traditional Chinese medicines (TCM), such as the flower of Lonicera japonica Thunb, the aerial parts of Artemisia capillaries Thunb and some frequently used TCM prescriptions containing these herb drugs [8].

Chlorogenic acid is also a useful starting material for the synthesis of derivatives with improved or new bioactivity. Adding a lipophilic chain at position 1 resulted in derivatives that could be taken up by hepatocytes and enhanced the inhibitory activity on hepatic glucose-6-phosphate translocase [9-11]. 
This enzyme catalyzes the final step in glycogenolytic and gluconeogenic pathways to liberate free glucose into the circulation, and inhibitors of this enzyme are potentially good for diabetic patients. Introducing a lipophilic chain and an amino acid residue to position 7 of chlorogenic acid led to potent anti-fungal compounds [12]. Adding lipophilic chains through acetal/ketal bonds to chlorogenic acid resulted in potent $\alpha$-glucosidase inhibitors [13]. $\alpha$-Glucosidase inhibitors could slow down the digestion and absorption of carbohydrates and thus are beneficial to type II diabetes patients.

Because of the important roles of this compound in human health, scientists have been making much effort to find and improve the synthesis method of chlorogenic acid. However, as there are several hydroxyl groups, a carboxyl, and an ester group in the structure, the task is quite difficult. In 2001, Sefkow reported the synthesis in higher yield of a quinic acid bisacetonide (1, structure shown in Scheme 1), in which the 1-OH, 1-COOH and 4,5-OH were protected and only 3-OH was free, and efficiently synthesized chlorogenic acid by reacting 1 with acetylcaffeoyl chloride followed by de-protection [14].

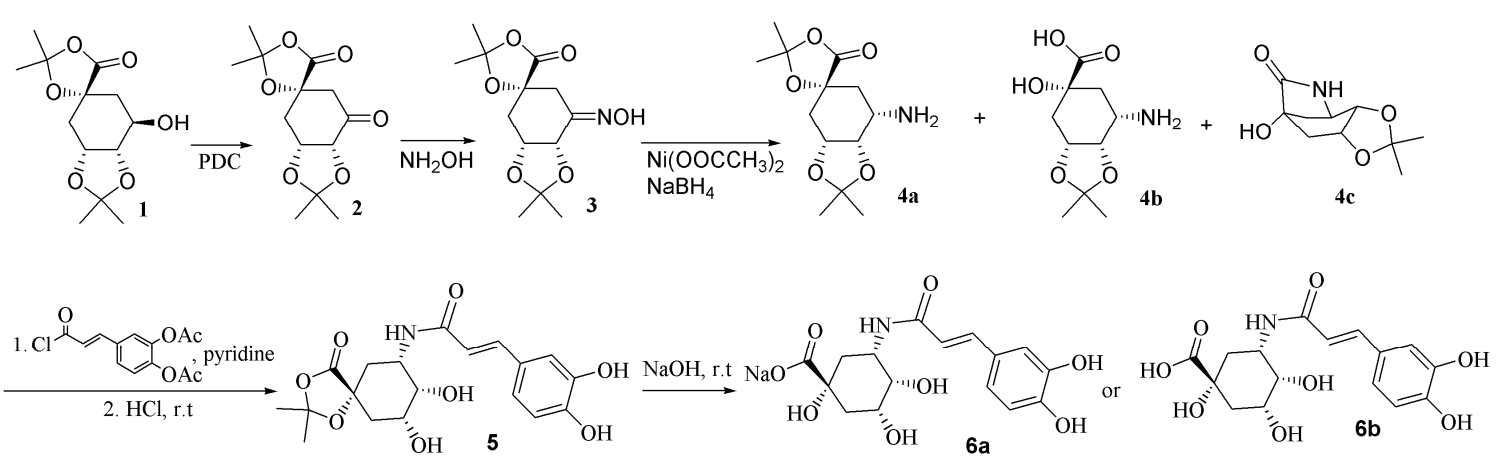

Scheme 1. Synthesis of a chlorogenic acid analogue with an amide bond.

It was observed that, although a small part of chlorogenic acid could be absorbed quickly, a large part of this compound was hydrolyzed in vivo through breakage of the ester bond between the caffeic and quinic acid moieties [15-17]. It is known that some bioactivity of chlorogenic acid could be lost if the ester bond was broken, such as in the case for the inhibition of hepatic glucose-6-phosphate translocase, chlorogenic acid showing good activity while neither caffeic acid nor quinic acid was active [9]. It is well documented that amides are more stable to esterase hydrolysis than esters, and if the ester bond of a compound was replaced by an amide bond, the stability would improve significantly $[17,18]$. Oxidative stress caused by reactive species of oxygen (ROS) damages cellular components and is recognized as one of the causes of chronic disease [19,20]. Human hepatoma cell line HepG2 is a reliable model for biochemical studies of intracellular antioxidant [21].

The present study aimed to synthesize and test the intracellular antioxidant activity of a chlorogenic acid analogue with an amide bond instead of the ester bond. In addition, the stability, anti-HCV activity, and toxicity on brine shrimps of this compound are described and compared with chlorogenic acid.

\section{Results and Discussion}

\subsection{Synthesis of $5 \alpha$-Caffeoylquinic Acid Amide}

The first step was to synthesize 3-amino-3-deoxy-quinic acid. Due to the multiple hydroxyl groups in the structure of quinic acid, it is difficult to force the reaction to occur in the desired position. The authors of [14] solved this problem by synthesis of compound 1 . The present research investigated the method to convert the hydroxyl group to amino group as described in detail in the following passage. The desired product was obtained by acylation of the amino intermediate and finally de-protection. 
As both acid sensitive (4,5-ketal) and alkaline sensitive (7-ester) groups exist in the structure of $\mathbf{1}$, reactions were carried out in conditions as mild as possible.

The synthesis route for the chlorogenic acid analogue from compound 1 [14] was depicted in Scheme 1. Compound 1 was firstly oxidized with pyridinium dichromate to give the ketone compound (2), which was then converted to the hydroxyimino compound (3) through reaction with $\mathrm{NH}_{2} \mathrm{OH} \cdot \mathrm{HCl}$. The next step, reduction of compound 3 to amino compound, was found to be very difficult. Compound 3 could not be hydrogenated by $\mathrm{H}_{2}-\mathrm{Ni}$ or $\mathrm{H}_{2}-\mathrm{Pt} / \mathrm{C}$ at $50{ }^{\circ} \mathrm{C}$, neither could it react with Ni-2-propanol. $\mathrm{TiCl}_{3}-\mathrm{NH}_{4} \mathrm{Ac}$ changed 3 back to 2 , possibly through fast hydrolysis of an imine intermediate which was formed by reduction of 3 . Treatment of 3 with $\mathrm{NaH}_{3} \mathrm{CN}+\mathrm{TiCl}_{3}$ resulted in a complex mixture, from which 4 could not be isolated. Finally, $\mathrm{Ni}\left(\mathrm{OOCCH}_{3}\right)_{2}$ and $\mathrm{NaBH}_{4}$ was used to react with 3 at low temperature. HR-MS revealed that the reaction mixture contained $4 \mathbf{a}, 4 \mathbf{b}$ and $4 \mathbf{c}$. The mixture was purified on an ODS column with the mobile phase kept at $0{ }^{\circ} \mathrm{C}$ to obtain a fraction containing mainly $4 a$ and $4 \mathbf{b}$. The mixture of $4 a$ and $4 \mathbf{b}$ was acylated with acetylcaffeoyl chloride followed by de-protection to afford $\mathbf{6 a}$ and $\mathbf{6} \mathbf{b}$.

Compound 6a displayed $\mathrm{m} / \mathrm{z}$ at 352 in negative ESI-MS. High resolution-FAB-MS $[\mathrm{M}-\mathrm{H}]^{-}$ showed $m / z 352.10167$ (Calcd. For $\mathrm{C}_{16} \mathrm{H}_{18} \mathrm{O}_{8} \mathrm{~N}$, requires 352.10322). Its ${ }^{1} \mathrm{H}-\mathrm{NMR}$ is quite similar to that of chlorogenic acid except that the H-5 signals at $\delta 4.56$ in $\mathbf{6 a}(\delta 4.23 \mathrm{in} \mathbf{6 b})$ is up-field shifted compared to that of chlorogenic acid at $\delta 5.33$. These data indicated that the ester bond was converted to an amide bond.

Compounds $\mathbf{6 a}$ and $\mathbf{6} \mathbf{b}$ were confirmed to be the salt form and free form of the same compound based on the following evidences. The mixture of $\mathbf{6 a}$ and $\mathbf{6} \mathbf{b}$ gave only one peak in the LC-MS analysis using an acidic mobile phase containing $0.1 \% \mathrm{HCOOH}$. When $6 \mathbf{a}$ was acidified with TFA and then concentrated, its ${ }^{1} \mathrm{H}-\mathrm{NMR}$ spectrum became exactly the same as that of $\mathbf{6} \mathbf{b}$.

To determine the orientation of the amide bond, nuclear Overhauser enhancement (NOE) experiment (see supporting material) was carried out for $\mathbf{6 a}$. When $\mathrm{H}-3$ was irradiated, significant NOE effects were observed for $\mathrm{H}-2, \mathrm{H}-4$ and $\mathrm{H}-5$, therefore $\mathrm{H}-3$ was in the same orientation as $\mathrm{H}-5$, i.e., in $\beta$-form, and thus the 3 -amide bond is in $\alpha$-orientation (Figure 1). For comparison, the NOE experiment of chlorogenic acid was also carried out (see supporting material). The $\mathrm{H}-3$ in chlorogenic acid was in $\alpha$-form and no NOE effect could be observed for H-5 when H-3 was irradiated.

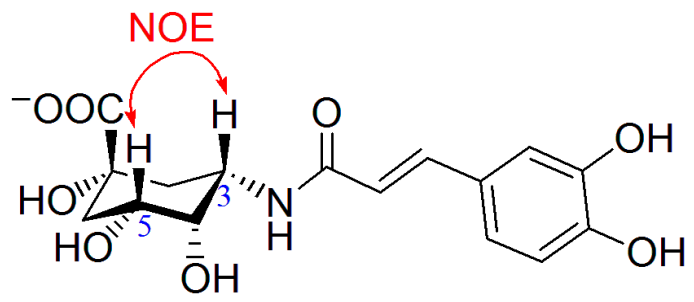

Figure 1. NOE interaction defining the configuration of C-3 in $\mathbf{6 a}$.

\subsection{Antioxidant Activity}

Using reported methods [21], the anti-oxidant activities of $\mathbf{6 b}$ and chlorogenic acid were compared. The results were expressed as $\mathrm{EC}_{50}$ representing the concentration $(\mu \mathrm{g} / \mathrm{mL})$ that produced $50 \%$ reduction of 2,2-diphenyl-1-picrylhydrazyl (DPPH) and $\mathrm{IC}_{50}$ representing the concentration $(\mu \mathrm{g} / \mathrm{mL})$ of SOD-like compound that inhibited the formation of WST-1 formazan by $50 \%$. The $\mathrm{EC}_{50}$ and $\mathrm{IC}_{50}$ values for $\mathbf{6 b}$ were found to be $17(\mu \mathrm{g} / \mathrm{mL})$ and $1.6(\mu \mathrm{g} / \mathrm{mL})$, respectively, and those for chlorogenic acid were $17(\mu \mathrm{g} / \mathrm{mL})$ and $1.5(\mu \mathrm{g} / \mathrm{mL})$, respectively. The results indicated that the amide analogue retained the strong anti-oxidant activity of chlorogenic acid. 


\subsection{Protection on HepG2 against $t$-BuOOH Induced Oxidative Stress}

Cytotoxic assay indicated that neither chlorogenic acid nor compound 6 were toxic on HepG-2 at $50 \mu \mathrm{g} / \mathrm{mL}$. In a dichlorofluorescein assay [18], a significant increase of ROS generation was observed in HepG2 cells treated with $t$-BuOOH as compared to non-stressed controls. Pretreatment with chlorogenic acid or compound 6 at $50 \mu \mathrm{mol} / \mathrm{L}$ remarkably decreased ROS generation as expressed by fluorescence (Figure 2).

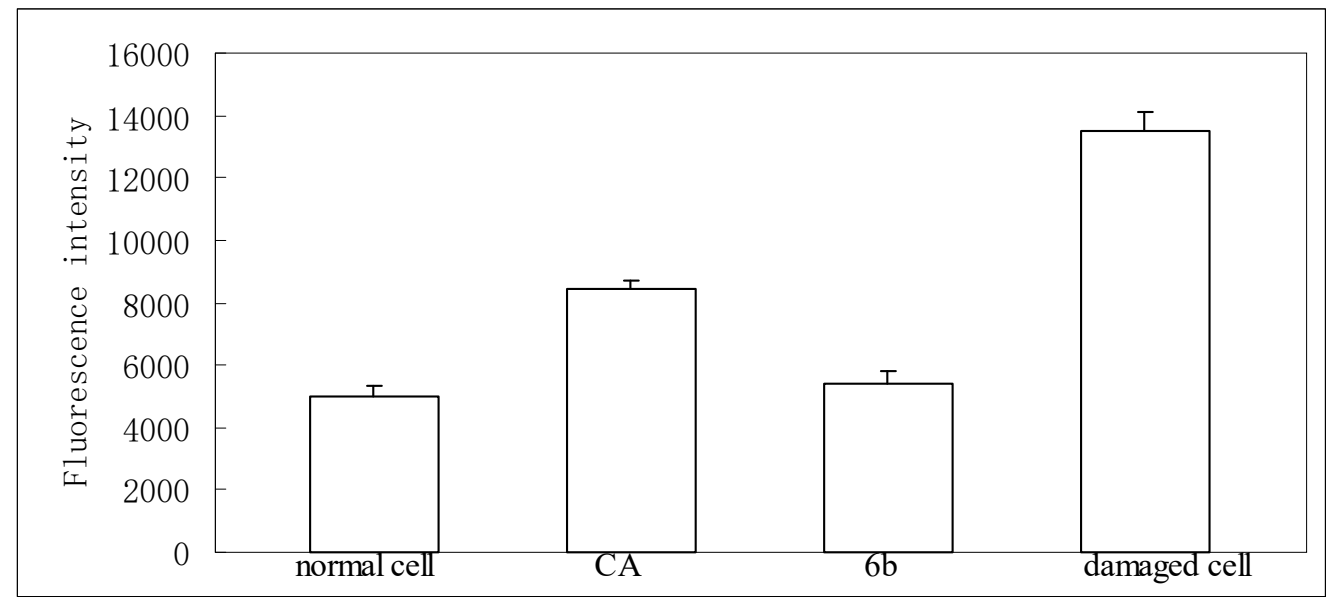

Figure 2. Inhibitory effect of chlorogenic acid (CA) and its amide analogue (6b) on reactive species of oxygen (ROS) formation.

\subsection{Anti-HCV Activity}

Anti-HCV activity was assessed by measuring the EGFP autofluorescence in HCV infected Huh-7.5 cell lines [22,23]. The values represent a mean of triplicate results of the declined percentage of EGFP autofluorescence activity. Compound $\mathbf{6 b}$ and chlorogenic acid showed $49.5 \%$ and $58.5 \%$ of inhibition, respectively, at a concentration of $100 \mu \mathrm{g} / \mathrm{mL}$. The results indicated that both chlorogenic acid and its amide analogue possess anti-HCV activity.

\subsection{Toxicity on Brine Shrimps}

The toxicity of chlorogenic acid and compound 6 was evaluated with Artemia salina L. (brine shrimps) assay using a reported method [24]. The concentration that caused $50 \%$ mortality $\left(\mathrm{LC}_{50}\right)$ of brine shrimp by chlorogenic acid and compound $\mathbf{6 b}$ were found to be 300 and $500 \mu \mathrm{g} / \mathrm{mL}$, respectively. The decreased toxicity of compound $\mathbf{6 b}$ as compared with chlorogenic acid may come from the much lower propensity for $\mathbf{6} \mathbf{b}$ to decompose forming more toxic compound, caffeic acid.

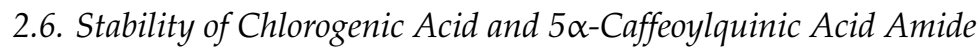

Stability tests were carried out in phosphate buffer (PBS) ( $\mathrm{pH} 7.4$ ) containing $\mathrm{MgCl}_{2}$, rat liver microsomes and $\beta$-NADPH. After $15 \mathrm{~h}$ incubation, about $50 \%$ of chlorogenic acid was decomposed to caffeic acid and quinic acid, while compound $\mathbf{6 b}$ was intact without any caffeic acid and quinic acid detected. This result is in accordance with the general metabolic concept that amides are more stable than esters [18].

\section{Experimental Section}

\subsection{Materials and Apparatus}

Caffeic acid, quinic acid and other chemical reagents were purchased from Sigma-Aldrich Corporation (St. Louis, MO, USA). Analytical grade solvents were used in the whole process. High 
performance liquid chromatography (HPLC) grade solvents used for UPLC were purchased from Fisher Scientific Company (Fair Lawn, NJ, USA). Octadecylsilane (ODS, 38-63 $\mu \mathrm{m}$ ) was purchased from Wako Pure Chemical Industries, Ltd., Osaka, Japan, Sephadex LH-20 was purchased from GE Healthcare Bio-Sciences AB, Uppsala, Sweden. NMR spectra were measured with a Varian Unity 500 $\left({ }^{1} \mathrm{H}, 500 \mathrm{MHz} ;{ }^{13} \mathrm{C}, 125 \mathrm{MHz}\right)$ spectrometer (Varian Co., Palo Alto, CA, USA) or a Bruker-500 $\left({ }^{1} \mathrm{H}\right.$, $500 \mathrm{MHz} ;{ }^{13} \mathrm{C}, 125 \mathrm{MHz}$ ) NMR spectrometer (Bruker Inc., Fällanden, Switzerland). UPLC-DAD-ESI-MS experiments were carried out on an Agilent 1290 infinity UPLC-DAD system (Agilent Technologies Singapore (International) Pte. Ltd., Singapore) coupled with an Agilent 6340 triple quad MS. Optical rotations were measured on a JASCO DIP-360 automatic polarimeter (JASCO Co., Tokyo, Japan). High resolution mass spectrum was measured on a Xevo G2 Q-TOF mass spectrometer (Waters, Milford, MA, USA) or a JEOL JMS-AX505W FAB-MS spectrometer (JEOL Co., Tokyo, Japan) with a resolution of 5000 using m-nitrobenzyl alcohol as the matrix. NMR spectra and HRMS data associated with this article can be found in the Supplementary.

\subsection{Chemical Synthesis}

The synthesis route was depicted in Scheme 1. Compound 1 [14] (23.2 g, $85.2 \mathrm{mmol})$, pyridinium dichromate $(50 \mathrm{~g}, 231.9 \mathrm{mmol})$ and molecular sieves $3 \AA \AA$ (70 g) were stirred in $\mathrm{CH}_{2} \mathrm{Cl}_{2}(300 \mathrm{~mL})$ at r.t. overnight. The mixture was passed through a short $\mathrm{SiO}_{2}$ column eluted with AcOEt:MeOH 99:1-95:5 to get $2(22.1 \mathrm{~g}, 81.8 \mathrm{mmol})$ in $96 \%$ yield. To a pyridine solution $(100 \mathrm{~mL})$ of $2(18 \mathrm{~g}, 66.6 \mathrm{mmol})$ was added $\mathrm{NH}_{2} \mathrm{OH} \cdot \mathrm{HCl}(16.3 \mathrm{~g}, 228.0 \mathrm{mmol})$. The mixture was stirred at $50{ }^{\circ} \mathrm{C}$ for $3 \mathrm{~h}$ followed by addition of 50 times (in volume) of $0.137 \mathrm{M}$ aq. $\mathrm{HCl}$. The mixture was passed through an ODS column eluted with $\mathrm{MeOH}-\mathrm{H}_{2} \mathrm{O}$. The product $(3,14 \mathrm{~g}, 49.1 \mathrm{mmol}, 73.7 \%$ ) was obtained from the $20 \%$ to $40 \% \mathrm{MeOH}$ eluted part. To $3(0.7 \mathrm{~g}, 2.5 \mathrm{mmol})$ in $7 \mathrm{~mL} \mathrm{MeOH}$ was added $\mathrm{Ni}\left(\mathrm{OOCCH}_{3}\right)_{2}(1.4 \mathrm{~g}, 7.91 \mathrm{mmol})$. The mixture was cooled in ice followed by addition of $\mathrm{NaBH}_{4}(0.65 \mathrm{~g}, 17.2 \mathrm{mmol})$ powder. The mixture was stirred at $0{ }^{\circ} \mathrm{C}$ for $4 \mathrm{~h}$ followed by addition of $30 \mathrm{~mL}$ ice- $\mathrm{H}_{2} \mathrm{O}$. The mixture was purified on ODS column while keeping the mobile phase at $0{ }^{\circ} \mathrm{C}$ to obtain a fraction containing mainly $4 \mathbf{a}$ and $4 \mathbf{b}$ (250 mg) from $20 \%$ to $50 \% \mathrm{MeOH}$ eluted part. To a $\mathrm{CH}_{2} \mathrm{Cl}_{2}$ solution $(10 \mathrm{~mL})$ of $4 \mathbf{a}$ and $4 \mathbf{b}(200 \mathrm{mg})$ were added DMAP ( $32 \mathrm{mg}, 0.30 \mathrm{mmol})$, pyridine $(3 \mathrm{~mL})$ and acetylcaffeoyl chloride $(0.56 \mathrm{~g}, 2.0 \mathrm{mmol})$. The reaction mixture was stirred at r.t. for $5 \mathrm{~h}$ and acidified with $1 \mathrm{M}$ aq. $\mathrm{HCl}$ to $\mathrm{pH}=3$. The organic solvent was evaporated and the residue was passed through an ODS column. The $60 \%-100 \%$ methanol eluted part was evaporated to dryness followed by treatment with $10 \mathrm{~mL} \mathrm{MeOH}-\mathrm{H}_{2} \mathrm{O}(4: 1)$ solution of $0.5 \mathrm{M} \mathrm{HCl}$ at r.t. overnight. After being concentrated to dryness, the mixture was treated with $6 \mathrm{~mL}$ $1 \mathrm{M} \mathrm{NaOH}$ and $9 \mathrm{~mL} \mathrm{MeOH}$ at r.t. for $1 \mathrm{~h}$ and then neutralized with $1 \mathrm{M} \mathrm{HCl}$ to $\mathrm{pH}=6$. The organic solvent was evaporated in vacuo at $40{ }^{\circ} \mathrm{C}$ and the residue passed through an ODS column eluted with $\mathrm{H}_{2} \mathrm{O}$ and then $90 \% \mathrm{MeOH}$. The $90 \% \mathrm{MeOH}$ eluted part was concentrated and further purified on a Sephadex LH 20 column eluted with $\mathrm{H}_{2} \mathrm{O}$ containing increasing amount of $\mathrm{MeOH}$. Compound 6a was obtained from the $10 \% \mathrm{MeOH}$ eluted part $(115 \mathrm{mg})$.

Acylation of $4 \mathbf{a}$ and $\mathbf{4 b}(100 \mathrm{mg})$ was carried in the same manner and deprotection of the intermediate product in the same procedure as described above, except for adjusting the solution to $\mathrm{pH}=3$ in the last step, to obtain $50 \mathrm{mg}$ of $6 \mathbf{b}$.

\subsection{Spectral Data}

Compound 2: white solid. HR-ESI-MS [M + Na] $]^{+} m / z 293.1004$ (Calcd. For $\mathrm{C}_{13} \mathrm{H}_{18} \mathrm{O}_{6} \mathrm{Na}$, requires 293.1001).

Compound 3: grey solid. HR-ESI-MS [M + H] $]^{+} m / z 286.1298$ (Calcd. For $\mathrm{C}_{13} \mathrm{H}_{20} \mathrm{NO}_{6}$, requires 286.1291).

Compound 4: grey solid. HR-ESI-MS of $4 \mathrm{a}[\mathrm{M}+\mathrm{H}]^{+} m / z 272.1502$ (Calcd. For $\mathrm{C}_{13} \mathrm{H}_{22} \mathrm{NO}_{5}$, requires 272.1498); HR-ESI-MS of $4 \mathbf{b}[\mathrm{M}+\mathrm{H}]^{+} m / z 232.1190$ (Calcd. For $\mathrm{C}_{10} \mathrm{H}_{18} \mathrm{NO}_{5}$, requires 232.1185), $[\mathrm{M}-\mathrm{H}]^{-} m / z 230.1034$ (Calcd. For $\mathrm{C}_{10} \mathrm{H}_{16} \mathrm{NO}_{5}$, requires 230.1028); HR-ESI-MS of $4 \mathbf{c}[\mathrm{M}+\mathrm{H}]^{+} \mathrm{m} / z$ 214.1082 (Calcd. For $\mathrm{C}_{10} \mathrm{H}_{16} \mathrm{NO}_{4}$, requires 214.1079). 
Compound 5: grey solid. HR-ESI-MS $[\mathrm{M}+\mathrm{H}]^{+} \mathrm{m} / z 394.1508$ (Calcd. For $\mathrm{C}_{19} \mathrm{H}_{24} \mathrm{NO}_{8}$, requires 394.1502), $[\mathrm{M}+\mathrm{Na}]^{+} m / z 416.1327$ (Calcd. For $\mathrm{C}_{19} \mathrm{H}_{23} \mathrm{NO}_{8} \mathrm{Na}$, requires 416.1321), $[\mathrm{M}-\mathrm{H}]^{-} \mathrm{m} / z$ 392.1343 (Calcd. For $\mathrm{C}_{19} \mathrm{H}_{22} \mathrm{NO}_{8}$, requires 392.1345).

Compound 6a (Sodium salt of $(1 R, 3 S, 4 S, 5 R)-3 \alpha$-[3-(3,4-dihydroxy-phenyl)-acryloylamino]-1,4,5trihydroxy-cyclohexanecarboxylic acid): white solid. $[\alpha]_{D}^{24}-14.8\left(\right.$ c $\left.0.19, \mathrm{CH}_{3} \mathrm{OH}\right) .{ }^{1} \mathrm{H}-\mathrm{NMR}\left(\mathrm{CD}_{3} \mathrm{OD}\right.$, $500 \mathrm{MHz}), \delta 1.87(\mathrm{~m}, 4 \mathrm{H}, \mathrm{H}-2 \mathrm{a}, 2 \mathrm{~b}$ and $6 \mathrm{a}, 6 \mathrm{~b}), 3.94(\mathrm{t}, J=2.5 \mathrm{~Hz}, 1 \mathrm{H}, \mathrm{H}-4), 4.25(\mathrm{ddd}, J=2.5,4.5,10.5$ $\mathrm{Hz}, 1 \mathrm{H}, \mathrm{H}-5), 4.56$ (ddd, $J=2.5,5.0,10.5 \mathrm{~Hz}, 1 \mathrm{H}, \mathrm{H}-3), 6.43\left(\mathrm{~d}, J=15.5 \mathrm{~Hz}, 1 \mathrm{H}, \mathrm{H}-8^{\prime}\right), 6.75$ (d, J = $8.0 \mathrm{~Hz}$, $\left.1 \mathrm{H}, \mathrm{H}-5^{\prime}\right), 6.89\left(\mathrm{dd}, J=2.0,8.0 \mathrm{~Hz}, 1 \mathrm{H}, \mathrm{H}-6^{\prime}\right), 7.00\left(\mathrm{~d}, J=2.0 \mathrm{~Hz}, 1 \mathrm{H}, \mathrm{H}-2^{\prime}\right), 7.37(\mathrm{~d}, J=15.5 \mathrm{~Hz}, 1 \mathrm{H}$, H-7'). ${ }^{13} \mathrm{C}-\mathrm{NMR}\left(\mathrm{CD}_{3} \mathrm{OD}, 125 \mathrm{MHz}\right), \delta 36.9$ (C-2), 39.2 (C-6), 49.7 (C-3), 69.9 (C-5), 71.6 (C-4), 74.6 (C-1), $115.0\left(\mathrm{C}-2^{\prime}\right), 116.4\left(\mathrm{C}-5^{\prime}\right), 118.9\left(\mathrm{C}-8^{\prime}\right), 122.1\left(\mathrm{C}-6^{\prime}\right), 128.4\left(\mathrm{C}-1^{\prime}\right), 142.0\left(\mathrm{C}-7^{\prime}\right), 146.7\left(\mathrm{C}-4^{\prime}\right), 148.7\left(\mathrm{C}-3^{\prime}\right)$, $168.8\left(\mathrm{C}-9^{\prime}\right), 181.9$ (C-7, salt form).

Compound $\mathbf{6 b}$ (Free acid of (1R,3S,4S,5R)-3 $\alpha$-[3-(3,4-Dihydroxy-phenyl)-acryloylamino]-1,4,5-trihydroxycyclohexanecarboxylic acid): white solid. $[\alpha]_{D}^{24}-26.1\left(c 0.5, \mathrm{CH}_{3} \mathrm{OH}\right) .{ }^{1} \mathrm{H}-\mathrm{NMR}\left(\mathrm{CD}_{3} \mathrm{OD}, 500 \mathrm{MHz}\right), \delta$ 1.90 (m, 2H,H-2a, H-6a), 2.02 (ddd, $J=3.0,4.5,13.0 \mathrm{~Hz}, 1 \mathrm{H}, \mathrm{H}-2 \mathrm{~b}), 2.14$ (dd, $J=4.0,13.0 \mathrm{~Hz}, 1 \mathrm{H}, \mathrm{H}-6 \mathrm{~b})$, $3.91(\mathrm{~m}, \mathrm{H}-4,5), 4.23(\mathrm{ddd}, J=2.0,4.5,12.5 \mathrm{~Hz}, 1 \mathrm{H}, \mathrm{H}-3), 6.46\left(\mathrm{~d}, J=15.5 \mathrm{~Hz}, 1 \mathrm{H}, \mathrm{H}-8^{\prime}\right), 6.77(\mathrm{~d}, J=$ $\left.8.0 \mathrm{~Hz}, 1 \mathrm{H}, \mathrm{H}-5^{\prime}\right), 6.92\left(\mathrm{dd}, J=2.0,8.0 \mathrm{~Hz}, 1 \mathrm{H}, \mathrm{H}-6^{\prime}\right), 7.03\left(\mathrm{~d}, J=2.0 \mathrm{~Hz}, 1 \mathrm{H}, \mathrm{H}-2^{\prime}\right), 7.40(\mathrm{~d}, J=15.5 \mathrm{~Hz}$, 1H, H-7'). ${ }^{13} \mathrm{C}-\mathrm{NMR}\left(\mathrm{CD}_{3} \mathrm{OD}, 125 \mathrm{MHz}\right), \delta 35.8$ (C-2), 38.1 (C-6), 49.3 (C-3), 69.1 (C-5), 71.2 (C-4), 73.9 (C-1), $115.1\left(\mathrm{C}-2^{\prime}\right), 116.4\left(\mathrm{C}-5^{\prime}\right), 118.5\left(\mathrm{C}-8^{\prime}\right), 122.1\left(\mathrm{C}-6^{\prime}\right), 128.4\left(\mathrm{C}-1^{\prime}\right), 142.4\left(\mathrm{C}-7^{\prime}\right), 146.7\left(\mathrm{C}-4^{\prime}\right), 148.7$ $\left(\mathrm{C}-3^{\prime}\right), 168.4\left(\mathrm{C}-9^{\prime}\right), 177.4$ (C-7). ESI-MS (Negative): $m / z 352.0[\mathrm{M}-\mathrm{H}]^{-} ;$HR-FAB-MS [M - H] $]^{-} m / z$ 352.10167 (Calcd. For $\mathrm{C}_{16} \mathrm{H}_{18} \mathrm{O}_{8} \mathrm{~N}$, requires 352.10322).

NOE experiment of $\mathbf{6 a}$ : When H-3 at $\delta 4.56$ was irradiated, significant NOE effects were observed for $\mathrm{H}-4, \mathrm{H}-5$ and $\mathrm{H}-2$ at $\delta 3.94,4.25$ and 1.87 , respectively.

NOE experiment of chlorogenic acid: When H-3 at $\delta 5.33$ was irradiated, significant NOE effects were observed for H-4 and $\mathrm{H}-2$ at $\delta 3.72$ and 2.21, respectively, but no NOE effect for H-5 at $\delta$ 4.17.

\subsection{Measurement of Radical Scavenging Activity and Superoxide Dismutase (SOD)-Like Activity}

Radical scavenging activity was evaluated on 96-well plates. To each well was added $10 \mu \mathrm{L}$ DMSO solution of a compound and $190 \mu \mathrm{L}$ ethanol solution of DPPH $(0.1 \mathrm{mM})$. The mixture was kept at $\mathrm{rt}$ for $20 \mathrm{~min}$ before the absorbance at $540 \mathrm{~nm}$ was measured using a plate reader (DNM-9602, Beijing Pu Long new technology Co. Ltd., Beijing, China). The radical scavenging activity was calculated as (effective rate $\%)=100 \times\left(\mathrm{A}_{\text {control }}-\mathrm{A}_{\text {compound }}\right) / \mathrm{A}_{\text {control}}$, where control wells contained DMSO instead of compound solution. Compounds were tested in triplicate at 4 concentrations and the $\mathrm{EC}_{50}$ values were calculated from the curves of effective rate $\%$ vs compound concentrations.

SOD-like activity was evaluated on 96-well plates using an SOD Assay Kit-WST (Dojindo Chemical, Kumamoto, Japan). To each well was added $20 \mu \mathrm{L}$ sample solution, $200 \mu \mathrm{L}$ WST working solution and $20 \mu \mathrm{L}$ xanthine oxidase solution. The plates were incubated at $37^{\circ} \mathrm{C}$ for $20 \mathrm{~min}$ before the absorbance at $450 \mathrm{~nm}$ was measured with the plate reader. The SOD-like activity represented as inhibition rate $\%$ was calculated with the following equation. SOD-like activity (inhibition rate $\%$ ) $=100$ $\times\left(\left(A_{\text {blank }} 1-A_{\text {blank }} 3\right)-\left(A_{\text {sample }}-A_{\text {blank }} 2\right)\right) /\left(A_{\text {blank }} 1-A_{\text {blank }} 3\right)$. Blank 1 contained water instead of sample solution; blank 2 contained buffer instead of enzyme; blank 3 contained water and buffer instead of sample solution and enzyme.

\subsection{Test for Anti-HCV Activity}

Anti-HCV activities were evaluated in vitro in an authentic HCV infection system in human hepatoma cell lines by measuring the EGFP autofluorescence as described in the literature $[22,23]$. Compound $\mathbf{6 b}$ and chlorogenic acid were tested at a final concentration of $100 \mu \mathrm{g} / \mathrm{mL}$. A positive control (HCV-796) [22] was tested at $0.4 \mu \mathrm{M}$ (showed $46.6 \%$ of inhibition). 


\subsection{Assay of the Toxicity on Brine Shrimps}

Brine shrimp assay was carried out using reported methods [24,25] with some modification. Ten larvae were placed in a tube containing 3.8\% $\mathrm{NaCl}$ water solution and different concentrations of compounds. After $2 \mathrm{~h}$, the survivor larvae were counted and the concentration that caused $50 \%$ mortality $\left(\mathrm{LC}_{50}\right)$ of brine shrimp was calculated.

\subsection{Cell Culture and Cytotoxic Assay}

HepG-2 cells in DMEM medium supplemented with 10\% FBS and 50 units/mL penicillin and $50 \mu \mathrm{g} / \mathrm{mL}$ streptomycin were cultured in a $5 \% \mathrm{CO}_{2}$ atmosphere at $37^{\circ} \mathrm{C}$. Cells were seeded in 96 -well plates at a rate of 50,000 cells per well. After addition of $\mathbf{6 b}$ and chlorogenic acid, the cells were cultured for $48 \mathrm{~h}$. MTT in PBS $(20 \mu \mathrm{L}$ of $5 \mathrm{mg} / \mathrm{mL})$ was added to each well and the plates were incubated at $37^{\circ} \mathrm{C}$. Four hours later, the medium was aspirated and the formazan was dissolved in DMSO for determination of absorbance at $570 \mathrm{~nm}$.

\subsection{Determination of ROS Formation in HepG2 Cells}

Determination of ROS formation in HepG2 cell was carried out using the dichlorofluorescin (DCFH) assay [26]. DCFH is non-fluorescent and can across the cell membrane freely. Intracellular ROS can oxidize DCFH to the fluorescent dichlorofluorescein DCF and the overall ROS could be estimated by measuring the fluorescence.

HepG-2 cells were plated in 96-well plate at a density of 20,000 cells per well and incubated for $4 \mathrm{~h}$ before chlorogenic acid and compound $6 \mathrm{~b}$ were added and further incubated for $24 \mathrm{~h}$. After the cells were washed once with a serum-free medium, $100 \mu \mathrm{L}$ of $10 \mu \mathrm{M}$ DCFH was added to each well. The plates were further incubated at $37^{\circ} \mathrm{C}$ for $30 \mathrm{~min}$. The cells were washed twice with a serum-free medium and then treated with $100 \mu \mathrm{L}$ of $400 \mu \mathrm{M}$ t-BuOOH and incubated for $1.5 \mathrm{~h}$. The liquid was discarded and $100 \mu \mathrm{L}$ PBS was added to each well, and the plates were immediately measured with a Tecan Infinite F200 PRO microplate reader at excitation/emission wavelengths of $490 \mathrm{~nm} / 520 \mathrm{~nm}$. The results were represented as the fluorescence intensity.

\subsection{Stability Test}

Stability test was carried out in phosphate buffered (PBS) ( $\mathrm{pH} 7.4$ ) containing $5.0 \mathrm{mM}$ of $\mathrm{MgCl}_{2}$. The reaction mixture comprised of $5 \mu \mathrm{L}$ DMSO solution of tested compound $(10 \mathrm{mg} / \mathrm{mL})$ and $100 \mu \mathrm{L}$ rat liver microsomes (protein $1.0 \mathrm{mg})$. The reaction was triggered with $5 \mu \mathrm{L}$ of $\beta-\mathrm{NADPH}(2.0 \mathrm{mM})$ and incubated at $37^{\circ} \mathrm{C}$ under agitation. An aliquot of $100 \mu \mathrm{L}$ of the mixture was taken at different time interval, and the reaction was stopped by addition of $200 \mu \mathrm{L}$ ice-cooled ethyl acetate. The mixture was evaporated in vacuo and the residue was dissolved in $80 \mu \mathrm{L}$ of methanol for LC-MS analysis.

\section{Conclusions}

We synthesized the chlorogenic acid analogue, $3 \alpha$-caffeoylquinic acid amide. This chlorogenic acid analogue was more stable than chlorogenic acid and retained the antioxidant and anti-viral activities of chlorogenic acid. The chlorogenic acid analogue showed stronger protective activity than chlorogenic acid on HepG-2 cells from tert-butyl hydroperoxide induced oxidation.

Chlorogenic acid has been used as a starting material to synthesize promising drug candidates. Using the presently synthesized amide analogue of chlorogenic acid as a starting material, it will be possible to synthesize more stable derivatives. The present procedure could also be applied to synthesize other acyl quinic acid amides, such as $p$-coumaroyl, feruloyl or galloylquinic acid amides. All the ester counterparts of these compounds are important bioactive natural products.

Supplementary Materials: The NMR and MS spectra are available online at www.mdpi.com/1420-3049/21/ 6/737/s1. 
Acknowledgments: This work was financially supported by Inner Mongolia Natural Science foundation (No. 2013MS1202). We would like to thank Wu-Hui Song, Shanghai Medical College, Fudan University for the anti-HCV assay. We would also like to thank He Meng, School of Chemistry and Chemical Engineering, Inner Mongolia University for measurement of NMR spectra and Jun Li of School of Pharmaceutical Sciences, Peking University for measurement of HRESIMS.

Author Contributions: Chao-Mei Ma, Masao Hattori and Mohsen Daneshtalab designed the research and guided the research; Ling-Na Wang, Wei Wang and Chao-Mei Ma performed the research and analyzed the data; Chao-Mei Ma and Ling-Na Wang wrote the paper. All authors, except for the late Mohsen Daneshtalab, read and approved the final manuscript. Our respected late Professor, Mohsen Daneshtalab read and approved a previous version of this manuscript.

Conflicts of Interest: The authors declare no conflict of interest.

\section{References}

1. Clifford, M.N. Chlorogenic acids and other cinnamates-nature, occurrence and dietary burden. J. Sci. Food Agric. 1999, 79, 362-372. [CrossRef]

2. Johnston, K.L.; Clifford, M.N.; Morgan, L.M. Coffee acutely modifies gastrointestinal hormone secretion and glucose tolerance in humans: Glycemic effects of chlorogenic acid and caffeine. Am. J. Clin. Nutr. 2003, 78, 728-733.

3. Morton, L.W.; Caccettah, R.A.-A.; Puddey, I.B.; Croft, K.D. Chemistry and biological effects of dietary phenolic compounds: Relevance to cardiovascular disease. Clin. Exp. Pharmacol. Physiol. 2000, 27, 152-159. [CrossRef] [PubMed]

4. Jassim, S.A.A.; Naji, M.A. Novel antiviral agents: A medicinal plant perspective. J. Appl. Microbiol. 2003, 95, 412-427. [CrossRef] [PubMed]

5. $\quad$ Feng, Y.; Yu, Y.H.; Wang, S.T.; Ren, J.; Camer, D.; Hua, Y.Z.; Zhang, Q.; Huang, J.; Xue, D.L.; Zhang, X.F.; et al. Chlorogenic acid protects D-galactose-induced liver and kidney injury via antioxidation and anti-inflammation effects in mice. Pharm. Boil. 2016, 1, 1027-1034. [CrossRef] [PubMed]

6. Lou, L.X.; Zhou, J.W.; Liu, Y.J.; Wei, Y.; Zhao, J.L.; Deng, J.G. Chlorogenic acid induces apoptosis to inhibit inflammatory proliferation of IL-6-induced fibroblast-like synoviocytes through modulating the activation of JAK/STAT and NF-kappa B signaling pathways. Exp. Ther. Med. 2016, 5, 2054-2060.

7. Fang, S.Q.; Wang, Y.T.; Wei, J.X.; Lu, X.M. Beneficial effects of Chlorogenic acid on alcohol-induced damage in PC12 cells. Biomed. Pharmacother. 2016, 4, 254-262. [CrossRef] [PubMed]

8. Chinese Pharmacopia Committee. Chinese Pharmacopia; China Medical Science and Technology Press: Beijing, China, 2010; pp. 205-206.

9. Schindler, P.W.; Below, P.; Hemmerle, H.; Burger, H.-J.; Screedhara, S.; Arion, W.J.; Efendic, S.; Herling, A.W. Identification of two new inhibitors of hepatic glucose-6-phosphate translocase. Drug Dev. Res. 1998, 44, 34-40. [CrossRef]

10. Hemmerle, H.; Burger, H.J.; Below, P.; Schubert, G.; Rippel, R.; Schindler, P.W.; Paulus, E.; Herling, A.W. Chlorogenic acid and synthetic chlorogenic acid derivatives: Novel inhibitors of hepatic glucose-6-phosphate translocase. J. Med. Chem. 1997, 40, 137-145. [CrossRef] [PubMed]

11. Schwab, D.; Herling, A.W.; Hemmerle, H.; Schubert, G.; Hagenbuch, B.; Burger, H.J. Hepatic uptake of synthetic chlorogenic acid derivatives by the organic anion transportproteins. J. Pharmacol. Exp. Ther. 2001, 296, 91-98. [PubMed]

12. Ma, C.M.; Kully, M.; Khan, J.K.; Hattori, M.; Daneshtalab, M. Synthesis of chlorogenic acid derivatives with promising antifungal activity. Bioorg. Med. Chem. 2007, 15, 6830-6833. [CrossRef] [PubMed]

13. Ma, C.M.; Hattori, M.; Daneshtalab, M.; Wang, L. Chlorogenic acid derivatives with alkyl chains of different lengths and orientations: Potent $\alpha$-glucosidase inhibitors. J. Med. Chem. 2008, 51, 6188-6194. [CrossRef] [PubMed]

14. Sefkow, M. First efficient synthesis of chlorogenic acid. Eur. J. Org. Chem. 2001, 6, 1137-1141. [CrossRef]

15. Nardini, M.; Cirillo, E.; Natella, F.; Scaccini, C. Absorption of phenolic acids in humans after coffee consumption. J. Agric. Food. Chem. 2002, 50, 5735-5741. [CrossRef] [PubMed]

16. Lafay, S.; Gil-Izquierdo, A.; Manach, C.; Morand, C.; Besson, C.; Scalbert, A. Chlorogenic acid is absorbed in its intact form in the stomach of rats. J. Nutr. 2006, 136, 1192-1197. [PubMed] 
17. Ma, C.M.; Abe, T.; Komiyama, T.; Wang, W.; Hattori, M.; Daneshtalab, M. Synthesis, anti-fungal and 1,3- $\beta$-D-glucan synthase inhibitory activities of caffeic and quinic acid derivatives. Bioorg. Med. Chem. 2010, 18, 7009-7014. [CrossRef] [PubMed]

18. Williams, D.A. Foye's Principles of Medicinal Chemistry; Lemke, T.L., Williams, D.A., Roche, V.F., Zito, S.W., Eds.; Lippincott Williams \& Wilkins: Philadephia, PA, USA, 2008; pp. 284-285.

19. Kehrer, J.P. Free radicals as mediators of tissue injury anddisease. Crit. Rev. Toxicol. 1993, 23, 21-48. [CrossRef] [PubMed]

20. Hyslop, P.A.; Hinshaw, D.B.; Halsey, W.A.; Schraufstatter, I.U.; Sauerheber, R.D.; Spragg, R.G.; Jackson, J.H.; Cochrane, C.G. Mechanisms of oxidant-mediated cell injury. J. Biol. Chem. 1988, 263, 1665-1675. [PubMed]

21. Alía, M.; Ramos, S.; Mateos, R.; Bravo, L.; Goya, L. Response of the antioxidant defense system to t-Butyl hydroperoxide and hydrogen peroxide in a human hepatoma cell line (HepG2). J. Biochem. Mol. Toxicol. 2005, 19, 119-128. [CrossRef] [PubMed]

22. Song, W.H.; Liu, M.M.; Zhong, D.W.; Zhu, Y.L.; Bosscher, M.; Zhou, L.; Ye, D.Y.; Yuan, Z.H. Tetrazole and triazole as bioisosteres of carboxylic acid: Discovery of diketotetrazoles and diketotriazoles as anti-HCV agents. Bioorg. Med. Chem. Lett. 2013, 23, 4528-4531. [CrossRef] [PubMed]

23. Liu, M.M.; Zhou, L.; He, P.L.; Zhang, Y.N.; Zhou, J.Y.; Shen, Q.; Chen, X.W.; Zuo, J.P.; Li, W.; Ye, D.Y. Discovery of flavonoid derivatives as anti-HCV agents via pharmacophore search combining molecular docking strategy. Eur. J. Med. Chem. 2012, 52, 33-43. [CrossRef] [PubMed]

24. Ma, C.M.; Kawahata, T.; Hattori, M.; Otake, T.; Wang, L.; Daneshtalab, M. Synthesis, anti-HIV and anti-oxidant activities of caffeoyl 5,6-anhydroquinic acid derivatives. Bioorg. Med. Chem. 2010, 18, 863-869. [CrossRef] [PubMed]

25. Ma, J.N.; Wang, S.L.; Zhang, K.; Wu, Z.G.; Hattori, M.; Chen, G.L.; Ma, C.M. Chemical components and antioxidant activity of the peels of commercial apple-shaped pear (fruit of Pyrus pyrifolia cv. pingguoli). J. Food Sci. 2012, 77, C1097-C1102. [CrossRef] [PubMed]

26. Alía, M.; Ramos, S.; Mateos, R.; Granado-Serrano, A.B.; Bravo, L.; Goya, L. Quercetin protects human hepatoma HepG2 against oxidative stress induced by tert-butyl hydroperoxide. Toxicol. Appl. Pharmacol. 2006, 212, 110-118. [CrossRef] [PubMed]

Sample Availability: Samples of compounds 1, 2, 3, 6a and $6 \mathrm{~b}$ are available from the authors.

(c) 2016 by the authors; licensee MDPI, Basel, Switzerland. This article is an open access article distributed under the terms and conditions of the Creative Commons Attribution (CC-BY) license (http://creativecommons.org/licenses/by/4.0/). 